\title{
PGAM1 wt Allele
}

National Cancer Institute

\section{Source}

National Cancer Institute. PGAM1 wt Allele. NCI Thesaurus. Code C132326.

Human PGAM1 wild-type allele is located in the vicinity of 10q24.1 and is approximately 7 $\mathrm{kb}$ in length. This allele, which encodes phosphoglycerate mutase 1 protein, plays a role in the glycolytic pathway. 